\title{
Psychological Distance terhadap Wise Reasoning pada Mahasiswa
}

\author{
Wawan Kurniawan ${ }^{1}$, Lukman, Nurfitriani Fakhri \\ Fakultas Psikologi Universitas Negeri Makassar
}

\begin{abstract}
Wisdom in an individual indicates a quality appearing naturally from integrated relationship of his existing traits. One of theories used in valuating wisdom is wise reasoning. It has six aspects that are analysis based on participants' responses to social dilemma. These aspects are perspective, change, flexibility, uncertainty or knowledge limit, compromise and conflict resolution. Wise reasoning can be affected by psychological distance (immersed and distance). The formulations of subject of this research are as follows; (1) Are there different wise reasoning in an individual doing self-immersion and one using self-distance? (2) Are there differences in wise reasoning between an individual having experienced a certain case and one having not experienced the same case? and (3) Are there differences in wise reasoning in an individual with a certain case and without the same case by using self-immersed and self-distance? The subjects of this research were 60 students from the State University of Makassar. The design used in this research was true experimental and randomized posttest only control group design. The results proved that psychological distance (immersed and distance) do not significantly contribute to wise reasoning.

Keywords: wise reasoning, psychological distance, students, experience
\end{abstract}

Abstrak. Keberadaan kebijaksanaan pada individu merupakan kualitas individu yang secara khas muncul dari hubungan integratif antara sejumlah karakter yang ada. Salah satu teori yang digunakan dalam menilai kebijaksanaan adalah wise reasoning. Wise Reasoning memiliki enam aspek yang dianalisis dari respon partisipan terhadap dilema sosial. Komponen-komponen tersebut adalah, perspektif, perubahan, fleksibel, ketidakpastian atau batas-batas pengetahuan, kompromi dan resolusi konflik. Wise reasoning dapat dipengaruhi oleh psychological distance (immersed and distance) Rumusan masalah penelitian ini adalah; (1) Apakah terdapat perbedaan wise reasoning pada individu yang melakukan self immersed dan individu yang menggunakan self distance? (2) Apakah terdapat perbedaan wise reasoning pada individu yang pernah mengalami kasus atau yang belum pernah mengalami kasus yang sama? dan (3) Apakah terdapat perbedaan wise reasoning pada individu dengan kasus yang dialami dan belum pernah dialami dengan menggunakan self immersed dan self distance? Subjek penelitian ini sebanyak 60 mahasiswa Universitas Negeri Makassar. Rancangan penelitian yang digunakan adalah true experimental (eksperimen murni) dengan desain penelitian randomized posttest only control group design. Hasil penelitian menunjukkan bahwa psychological distance (immersed and distance) tidak memberikan hasil yang signifikan terhadap wise reasoning.

Kata kunci: wise reasoning, psychological distance, mahasiswa, pengalaman

\footnotetext{
1) Korespondensi mengenai artikel ini dapat dilakukan melalui: wawan.kurniawan1992@gmail.com
} 
Semua orang dapat menjadi bijaksana. Individu mampu menganalisis kehidupan yang pernah dialami dari pengalaman tersebut kemudian mengambil pelajaran penting untuk digunakan di masa depan. Dengan cara ini mereka bisa bertindak lebih baik. Apalagi jika pengalaman yang pernah dialami tersebut memiliki konsekuensi penting bagi individu (Staudinger \& Bluck, 2004). Sebaliknya, individu yang belum pernah mengalami suatu kejadian hanya bisa memprediksi apa yang akan terjadi dan belum dapat mengambil pelajaran dari pengalaman prediktif tersebut.

Selain kemampuan menganalisis pengalaman, penjelasan lain tentang kebijaksanaan menyebutkan bahwa, kebijaksanaan adalah sebuah penilaian yang baik dari sebuah perilaku. Penilaian baik yang dimaksud adalah pertimbangan menyeluruh dari sejumlah aspek pada situasi tertentu ketika individu mengalami masalah. Sebagai contoh, individu akan menilai kelebihan dan kekurangan dari penilaiannya, bagaimana emosinya ketika mengambil suatu keputusan, serta mempertimbangan situasi sosial dan budaya (Lerner, Easterbrooks \& Mistry, 2003). Tentu saja, penilaian yang baik ini akan muncul ketika individu sudah pernah mengalami masalah, atau belajar dari pengalaman orang lain. Misalnya, ketika individu mengambil suatu keputusan, dan keputusan tersebut keliru, di masa depan, ia dapat lebih berhati-hati dan lebih mempertimbangkan faktor di masa lalu yang ia peroleh. Penelitian Grossmann dkk (2010) menemukan bahwa, orangtua dibandingkan dengan remaja dan dewasa awal ternyata lebih bijaksana, karena mereka telah memiliki beragam pengalaman. Dan karena pengalaman tersebut, membuat mereka lebih bijak ketika menghadapi masalah yang sama dikemudian hari. Oleh karena itu, salah satu faktor yang dapat memengaruhi "penilaian baik" seseorang adalah pernah atau tidaknya seseorang mengalami masalah tersebut.

Pendapat lain dari Staudinger (1994) menyatakan bahwa, kebijaksanaan dapat diartikan sebagai kemampuan dasar dari proses berpikir individu. Ini berarti bahwa orang yang bijaksana adalah mereka yang menggunakan dan mengkaitkan pengetahuan serta wawasan hidup (termasuk perkembangan yang terjadi pada diri sendiri), penilaian atas tanggapan orang lain terhadap perilakunya, penilainnya terhadap kualitas hubungan sosialnya, antar individu maupun antar generasi, tugas dan tujuan kehidupan, serta variasi budaya dalam kehidupannya. Selain pendapat tersebut, masih ada pendapat lain dari Baltes, dkk (1992); Sternberg (2005) yang menyatakan bahwa kebijaksanaan pada individu merupakan kualitas individu yang secara khas muncul ketika mereka berhubungan dengan individu lain dengan karakter yang berbeda. Baltes dan Smith (1990) juga menyatakan bahwa, "kebijaksanaan adalah penilaian yang baik dan nasihat-nasihat penting pada kondisi yang tidak pasti dalam kehidupan.

Dari beragam pendapat ini, meskipun terdapat banyak penjelasan untuk mendefinisikan kebijaksanaan (Staudinger \& Glück, 2011), pendapat yang paling kuat menyatakan bahwa kebijaksanaan adalah pengetahuan awal yang dijadikan alasan oleh seseorang untuk merespons sesuatu (alasan pragmatis). Alasan tersebut membantu individu untuk mengarahkan tindakannya ketika menghadapi masalah sosial, contohnya, bagaimana seseorang bertindak ketika mengalami konflik antar individu atau antar grup (Grossmann dkk., 2010). Hanya saja, menurut Grossmann dkk., ruang lingkup kebijaksanaan atau perilaku yang dapat ditampilkan sulit untuk ditentukan. Dari beragam 
pendapat tersebut, terlihat bahwa ada banyak cara untuk dapat menjelaskan kebijaksanaan. Namun, salah satu gambaran sederhana untuk menjelaskan konsep kebijaksanaan yang beragam tersebut menurut Aldert (Sternberg, 2005) adalah kembali membaca cerita dari Buddha. Kisah "orang buta dan gajah", menceritakan bahwa, pada zaman dahulu terdapat raja yang mengundang sejumlah orang yang mengalami kebutaan sejak lahir untuk menjelaskan arti gajah. Setelah terkumpul, orang buta diminta untuk menjelaskan gajah yang diletakkan di depan mereka. Setiap dari orang buta memberikan pengertian yang berbeda, tergantung dari bagian yang mereka sentuh. Dengan analogi orang buta dan gajah ini, kebijaksanaan dapat dijelaskan menurut teori yang berbeda-beda.

Salah satu teori yang digunakan untuk menilai kebijaksanaan adalah wise reasoning. Wise reasoning adalah kemampuan bernalar seseorang yang diukur dari enam aspek ketika individu menghadapi suatu dilema sosial (Basseches, 1980; Kramer, 1986; Staudinger \& Glück, 2011). Keenam aspek tersebut adalah: (1) mempertimbangkan perspektif orang yang terlibat dalam konflik (perspective); (2) mengakui kemungkinan terjadinya perubahan (change); (3) mengakui beberapa cara mengatasi atau menemukan solusi atas suatu konflik (flexible) (4) mengakui ketidakpastian dan batas-batas pengetahuan (limit of knowledge) (5) mengakui pentingnya/mencari kompromi antara sudut pandang yang bertentangan (compromise); dan (6) mengakui pentingnya/memprediksi resolusi konflik (resolution).

Penelitian yang berkaitan dengan kebijaksanaan menurut pengetahuan peneliti tidak pernah dilakukan di Makassar. Bisa saja penelitian yang terkait dengan kebi- jaksanaan sudah pernah dilakukan namun karena belum sepakatnya ahli mengenai konsep kebijaksanaan dalam psikologi, maka penelitian tersebut mungkin menggunakan nama konstruk yang berbeda. Hasil focus group discussion (FGD) peneliti yang dilakukan pada lima mahasiswa Universitas Negeri Makassar (UNM) menunjukkan bahwa kebijaksanaan dapat diartikan sebagai kemampuan untuk memutuskan dan menimbang sesuatu dengan tepat. Jika konsep ini digunakan, kebijakasanaan berkaitan dengan kemampuan menalar (reasoning) dan mengambil keputusan (decision making). Pendapat ini ternyata sejalan dengan pendapat Baltes dan Smith (1990) yang menyatakan bahwa, kebijaksanaan adalah "penilaian yang baik" yang telah dijelaskan sebelumnya.

Lebih lanjut peneliti menemukan bahwa, pada FGD tersebut, terdapat pula sejumlah perilaku bijaksana dan tidak bijaksana mahasiswa di kampus yang dikemukakan partisipan. Yang termasuk perilaku bijaksana diantaranya, mampu menjaga kebersihan kampus, belajar dengan sungguh-sungguh, mampu membantu teman atau orang lain, dan dapat mempertimbangkan setiap langkah yang ditempuh. Sedangkan perilaku yang mencerminkan ketidakbijaksanaan, diantaranya melakukan plagiat, mementingkan diri sendiri, hedonisme-memetingkan kesenangan dan mengabaikan waktu untuk belajar. Hasil ini secara umum sesuai dengan teori perilaku bijaksana yang disebutkan oleh Sternberg (2005). Menurut Sternberg, orang-orang yang bijak adalah mereka yang membuat keputusan dengan "benar", namun untuk mengetahui keputusan yang benar, dilihat dari perilaku mereka yang lebih baik.

Terlepas dari ketidaksepakatan tentang konstruk kebijaksanaan, para ahli 
sepakat, bahwa kebijaksanaan dibutuhkan individu. Mahasiswa perlu bijak dalam menjalani kehidupan kampus, ataupun kehidupan sehari-harinya. Untuk mengetahui tingkat kebijaksanaan mahasiswa, peneliti melakukan studi kecil pada sampel terbatas untuk mengukur tingkat kebijaksanaan mahasiswa. Dari 10 mahasiswa dengan angkatan berbeda (20102014), hanya satu orang yang memiliki tingkat kebijak-sanaan yang tergolong dalam kategori sedang, dan 9 orang lainnya berada pada kategori rendah. Studi ini menggunakan teori wise reasoning dari Grossman (2011). Hasil studi ini membuat peneliti tertarik untuk meneliti lebih lanjut kebijaksanaan (wise reasoning) mahasiswa UNM.

Penelitian sebelumnya yang menggunakan konstruk wise reasoning dilakukan oleh Kross dan Grossman (2011) pada 57 mahasiswa Universitas Michigan (35 perempuan dan 22 laki-laki). Penelitian ini bertujuan untuk mengetahui bagaimana cara untuk menjadi bijaksana. Penelitian tersebut menyatakan bahwa, individu dapat gagal menjadi bijaksana jika alasan atas masalah yang dimilikinya memiliki kaitan pribadi (immersed). Dengan kata lain, untuk menjadi bijaksana individu perlu mengambil jarak dengan masalah yang sedang ia alami (distance). Penelitian mereka membuktikan bahwa self-distance secara signifikan dapat membuat individu lebih bijaksana. Pada kondisi immersed individu menempatkan dirinya pada "pandangan diri sendiri", sedangkan pada kondisi distance atau "fly in the wall perspective", individu menganalisis perasaan dan masalah yang dialami bukan menurut pandangan sendiri tetapi dengan memandang dari sudut pandang orang lain. Walaupun ada enam aspek untuk mengukur tingkat kebijakasanaan (wise reasoning) individu. Namun, penelitian
Kross dan Grossmann hanya menggunakan dua aspek saja, yaitu change dan limit. Menurut Kross dan Grossmann, pengukuran wise reasoning disesuaikan dengan kasus yang dialami oleh individu.

Ketika individu mencerminkan pengalaman saat marah, dengan self-distance, individu dapat melihat diri (self) dari jarak yang jauh. Pada kondisi ini, mereka mampu melihat situasi lebih luas dibandingkan berada pada pandangan sebagai "pelaku" (Kross \& Ayduck, 2011). Alford dan Beck (Kross \& Ayduck, 2011) menjelaskan bahwa, "distancing" berhubungan dengan kemampuan untuk melihat pemikiran sendiri atau keyakinan diri sebagai konstruk realitas dan bukan sebagai realitas itu sendiri.

Self-distance juga dapat mengatasi permasalahan atau pengalaman negatif individu. Kross, dkk. (2005) menyatakan bahwa upaya orang untuk menganalisis pengalaman negatif sering gagal karena individu fokus atau tenggelam pada perasaan mereka sendiri (memvisualisasikan pengalaman masa lalu melalui diri mereka sendiri) daripada perspektif self-distance (memvisualisasikan pengalaman masa lalu dari perspektif pengamat atau observer).

Penelitian ini menguji wise reasoning dengan membandingkan mahasiswa yang sudah pernah atau belum pernah mengalami kasus ketidakadilan di kampus dengan menggunakan pendekatan selfdistance dan self-immersed. Peneliti berasumsi bahwa individu akan memiliki kebijaksanaan yang lebih baik ketika berada pada situasi ketidakadilan jika menggunakan self-distance, atau melihat kondisi atau masalah dari posisi pengamat. Pada posisi tersebut, individu akan lebih mudah memahami masalah dan bernalar untuk mengatasi permasalahan yang terjadi pada dirinya sendiri. Individu dengan self-distance secara umum dengan 
mempertimbangkan sejumlah kemungkinan yang terjadi tanpa ada tekanan dan dapat berpikir secara objektif. Selain itu, mereka akan lebih bijaksana jika sudah pernah mengalami kasus tersebut karena akan bertindak dengan lebih baik dari pada mereka yang belum pernah mengalami. Proposisi tersebut dibangun dari teori psychological distance dari Kross dan Ayduk (2010).

Pada penelitian ini terdapat tiga hipotesis. Hipotesis pertama yang diajukan dalam penelitian ini adalah terdapat perbedaan wise reasoning pada individu yang melakukan self-immersed dan individu yang menggunakan self-distance. Individu yang menggunakan self-distance, akan memiliki wise reasoning yang lebih tinggi dibandingkan jika menggunakan self-immerse. Hipotesis kedua, terdapat perbedaan wise reasoning pada individu yang pernah mengalami kasus atau yang belum pernah mengalami kasus yang sama. Individu yang sudah pernah mengalami kasus akan memiliki wise reasoning lebih tinggi dibandingkan yang belum pernah mengalaminya. Hipotesis ketiga, terdapat perbedaan wise reasoning pada individu dengan kasus yang dialami dan belum pernah dialami dengan menggunakan self-immersed dan self-distance. Individu yang pernah mengalami dan menggunakan self distance akan memiliki wise reasoning yang lebih tinggi dari pada kondisi yang lain.

\section{Metode}

\section{Variabel}

Penelitin ini menggunakan dua variabel bebas, yaitu psychologycal distance (immersed dan distance), dan pengalaman (belum dan pernah) dan variabel terikat yaitu wise reasoning.
Subjek

Partisipan adalah 60 orang mahasiswa UNM yang terdiri dari 13 laki-laki dan 47 perempuan. Penentuan partisipan dilakukan dengan memberikan pengumuman pada tiap kordinator kelas. Koodinator kemudian memberikan nama-nama mahasiswa yang bersedia untuk menjadi partisipan.

Desain

Rancangan penelitian yang digunakan adalah true experimental dengan randomized posttest only control group design. Desain tersebut membuat dua kondisi yang berbeda pada dua kelompok penelitian (Seniati, Yulianto \& Setiadi, 2005). Kelompok eksperimen akan diberi perlakuan sedangkan kelompok kontrol tidak diberikan perlakuan. Dua kelompok ini kemudian dibandingkan.

\section{Manipulasi}

Untuk menguji hipotesis pertama, kedua, dan ketiga partisipan dibagi dalam dua kelompok yang terdiri dari kelompok immersed dan distance secara random. Pada saat partisipan terkumpul, peneliti membaginya dalam dua kelompok, dengan cara berhitung " 1 " dan " 2 ". Bagi peserta yang mendapatkan angka 1 akan diberikan posisi immersed $(n=30)$ dan $2(n=30)$ akan diberikan posisi distance. Setelah terbagi dalam dua kelompok, partisipan akan diberikan sebuah kasus untuk melihat wise reasoning yang dimiliki. Kasus tersebut diperoleh setelah peneliti menyebarkan angket kepada 90 mahasiswa UNM. Pada angket tersebut, terdapat pilihan tentang sejumlah hal penting yang ada di lingkungan kampus. Hasil yang diperoleh menunjukkan bahwa "hubungan dengan teman" menjadi jawaban paling tinggi. Sehingga peneliti merancang kasus tentang kondisi dalam sebuah kelompok tugas. Pada kasus tersebut, diceritakan 
bahwa terdapat seorang mahasiswa yang rajin, bergabung dengan teman yang kurang aktif dalam proses pengerjaan tugas. Namun, pada saat nilai final terjadi hal yang sebaliknya. Nilai mahasiswa rajin lebih rendah di-bandingkan dengan nilai temannya, mahasiswa yang kurang aktif.

Sebelum mengerjakan kasus tersebut, partisipan diminta untuk memahami dengan baik kasus tersebut, dan kemudian diberikan beberapa pertanyaan. Pada pertanyaan awal, partisipan diminta untuk kembali mengingat apakah kasus tersebut pernah atau belum dialami. Pertanyaan tersebut untuk menjawab hipotesis kedua. Selanjutnya terdapat empat pertanyaan untuk menilai wise reasoning dari peserta. Pertanyaan tersebut adalah sebagai berikut: (1) Apa penyebab dari kasus tersebut? (2) Bagaimana hasil akhir dari kasus tersebut? (3) Apa yang akan terjadi selanjutnya atau akan berkembang dari kondisi tersebut? dan (4) Solusi apa yang dapat anda berikan untuk kasus tersebut?

Kasus diberikan dalam lembaran soal yang telah disesuaikan berdasarkan kelompok yang ada, yakni immersed dan distance. Perbedaan kelompok akan dibedakan berdasarkan instruksi yang diberikan kepada partisipan. Kelompok immersed, diberikan instruksi, untuk berada pada posisi diri mereka. Kelompok distance, diberikan instruksi, untuk membayangkan diri mereka pada kasus yang sama, namun mereka diminta untuk mengamati kasus tersebut dengan cara "distancing", seperti tidak sedang terlibat didalamnya.

Pada penelitian ini, peneliti juga melakukan korespondensi dengan Igor Grossman melalui email. Hal tersebut dilakukan untuk menentukan aspek yang dapat diteliti pada wise reasoning. Penjelasan yang didapatkan bahwa untuk melakukan pengukuran terhadap wise reasoning dapat ditentukan berdasarkan kasus yang telah didapatkan (Grossman, 2015). Kasus dalam penelitian ini, terkait dengan topik hubungan dengan teman dapat dikategorikan sebagai interpersonal konflik. Sehingga, peneliti memutuskan untuk mengukur change dan limit of knowledge. Dua aspek tersebut digunakan Igor Grossman pada saat penelitian psychological distance dalam memengaruhi wise reasoning.

\section{Pengumpulan Data}

Data diperoleh dari analisis terhadap sejumlah jawaban partisipan dari kasuskasus yang dibagikan. Ada dua rater yang akan memberikan penilaian terhadap jawaban partisipan. Penilaian tersebut akan mengikuti model penilaian dari Grossman (2011). Jawaban partisipan yang diperoleh dari kasus yang telah disusun oleh peneliti untuk direspons akan menentukan bagaimana tingkat kebijaksanaan individu. Rater dilatih selama lima minggu untuk mengukur keakuratan dan tingkat reliabilitasnya dalam mengukur wise reasoning. Pelatihan penilaian wise reasoning menggunakan buku manual wise reasoning dari Grossman. Kasus yang dinilai diperoleh dari angket yang disebarkan kepada mahasiswa. Data yang diperoleh kemudian digunakan sebagai topik kasus yang akan didiskusikan oleh partisipan. Reliabilitas jawaban dari dua orang rater diuji dengan menggunakan Uji Cohen Kappa.

\section{Prosedur}

Tahap-tahap dalam penelitian ini yaitu: (1) peneliti memberikan kasus yang telah disusun (2) membagi subjek dalam dua kelompok, dan (3) setelah terdapat kelompok, peneliti memberikan pertanyaan untuk menguji wise reasoning dari para peserta. 


\section{H a s i 1}

\section{Statistika Deskriptif}

Berdasarkan penelitian yang dilakukan, maka diperoleh hasil statistik deskriptif yang disajikan dalam Tabel 1.

Uji Homogenitas

Uji homogenitas menunjukkan bahwa variabel change homogen hasil Levene test untuk aspek change menunjukkan nilai $F=1.372 p=0,261 \quad(p>0.05)$, maka data dalam penelitian ini dinyatakan bersifat homogen. Hasil Levene test untuk aspek limit menunjukkan nilai $F=15.755 p=0,00$ $(p<0.05)$, maka data dalam penelitian ini dinyatakan tidak homogen.

Tabel 1

Deskripsi wise reasoning pada aspek change dan limit

\begin{tabular}{|c|c|c|c|c|}
\hline Wise Reasoning & & & & \\
\hline \multirow[t]{2}{*}{ Change hipotetik } & $\operatorname{Max}$ & Min & $S D$ & Mean \\
\hline & 3 & 1 & 0,33 & 2 \\
\hline \multirow[t]{2}{*}{ Change empiric } & $\operatorname{Max}$ & Min & $S D$ & Mean \\
\hline & 3 & 1 & 0,3 & 2,07 \\
\hline \multirow[t]{4}{*}{ Kategorisasi change } & & $n$ & $\%$ & \\
\hline & Tinggi & 6 & 10,0 & \\
\hline & Sedang & 52 & 86,7 & \\
\hline & Rendah & 2 & 3,3 & \\
\hline \multirow[t]{2}{*}{ Limit hipotetik } & $\operatorname{Max}$ & Min & $S D$ & Mean \\
\hline & 3 & 1 & 0,33 & 2 \\
\hline \multirow[t]{2}{*}{ Limit empirik } & $\operatorname{Max}$ & Min & $S D$ & Mean \\
\hline & 2 & 1 & 0,181 & 1,03 \\
\hline \multirow[t]{4}{*}{ Kategorisasi Limit } & & $N$ & $\%$ & \\
\hline & Tinggi & 0 & 0 & \\
\hline & Sedang & 2 & 3,3 & \\
\hline & Rendah & 58 & 96,7 & \\
\hline
\end{tabular}




\section{KURNIAWAN DKK.}

Tabel 2

Deskripsi psychological distance

\begin{tabular}{|c|c|c|c|c|}
\hline \multicolumn{5}{|c|}{ Psychological distance } \\
\hline \multirow{2}{*}{ Immersed hipotetik } & $\operatorname{Max}$ & Min & $S D$ & Mean \\
\hline & 3 & 1 & 0,33 & 2 \\
\hline \multirow[t]{2}{*}{ Immersed empirik } & $\operatorname{Max}$ & Min & $S D$ & Mean \\
\hline & 3 & 1 & 0,371 & 2 \\
\hline \multirow[t]{4}{*}{ Kategorisasi Immersed } & & $n$ & $\%$ & \\
\hline & Tinggi & 2 & 3,3 & \\
\hline & Sedang & 26 & 43,3 & \\
\hline & Rendah & 2 & 3,3 & \\
\hline \multirow[t]{2}{*}{ Distance hipotetik } & Max & Min & $S D$ & Mean \\
\hline & 3 & 1 & 0,33 & 2 \\
\hline \multirow[t]{2}{*}{ Distance empirik } & $\operatorname{Max}$ & Min & $S D$ & Mean \\
\hline & 3 & 2 & 0,346 & 2,13 \\
\hline \multirow[t]{4}{*}{ Kategorisasi Distance } & & $N$ & $\%$ & \\
\hline & Tinggi & 4 & 6,7 & \\
\hline & Sedang & 26 & 43,3 & \\
\hline & Rendah & 0 & 0 & \\
\hline
\end{tabular}

Tabel 3

Deskripsi pengalaman

\begin{tabular}{lcc}
\hline & Pengalaman kasus & \\
\hline Belum pernah mengalami & $N$ & $\%$ \\
& 18 & 30 \\
Sudah pernah Mengalami & $N$ & $\%$ \\
& 42 & 70 \\
\hline
\end{tabular}

Uji Normalitas

Tabel 4.

Psychological Distance

\begin{tabular}{|c|c|c|c|c|c|c|c|}
\hline & \multirow{2}{*}{$\begin{array}{l}\text { Psychological } \\
\text { distance }\end{array}$} & \multicolumn{3}{|c|}{ Kolmogorov-Smirnov(a) } & \multicolumn{3}{|c|}{ Shapiro-Wilk } \\
\hline & & Statistic & $d f$ & $p$ & Statistic & $d f$ & $p$ \\
\hline \multirow{2}{*}{ Wise } & Immersed & 0,256 & 30 & 0,000 & 0,875 & 30 & 0,002 \\
\hline & Distance & 0,240 & 30 & 0,000 & 0,855 & 30 & 0,001 \\
\hline
\end{tabular}

Tabel 5. Pengalaman

\begin{tabular}{|c|c|c|c|c|c|c|c|}
\hline & \multirow{2}{*}{ Pengalaman } & \multicolumn{3}{|c|}{ Kolmogorov-Smirnov(a) } & \multicolumn{3}{|c|}{ Shapiro-Wilk } \\
\hline & & Statistic & $d f$ & Sig. & Statistic & $D f$ & Sig. \\
\hline \multirow{2}{*}{ Wise } & Pernah & 0,192 & 18 & 0,079 & 0,934 & 18 & 0,225 \\
\hline & Belum & 0,229 & 42 & 0,000 & 0,843 & 42 & 0,000 \\
\hline
\end{tabular}


Uji Hipotesis

Karena tidak memenuhi asumsi normalitas, maka uji hipotesis kemudian menggunakan statistik non-parametrik.

Hipotesis Pertama

Tabel 6

Deskripsi Psychological Distance

\begin{tabular}{lccccc}
\hline & $N$ & Mean & $\begin{array}{c}\text { Std. } \\
\text { Dev. }\end{array}$ & Min. & Max. \\
\hline Wise & 60 & 9,12 & 1,316 & 7 & 13 \\
psi_distance & 60 & 1,50 &, 504 & 1 & 2 \\
\hline
\end{tabular}

Tabel 7

Mean Rank Psychological Distance

\begin{tabular}{|c|c|c|c|c|}
\hline \multirow{4}{*}{ Wise } & psi_distance & $N$ & $\begin{array}{l}\text { Mean } \\
\text { Rank }\end{array}$ & $\begin{array}{l}\text { Sum of } \\
\text { Ranks }\end{array}$ \\
\hline & immersed & 30 & 27,18 & 815,50 \\
\hline & distance & 30 & 33,82 & 1014,50 \\
\hline & Total & 60 & & \\
\hline
\end{tabular}

Tabel 8

Uji U-Mann Whitney Psychological Distance

\begin{tabular}{ll}
\hline & Wise \\
\hline Mann-Whitney U & 350,500 \\
Wilcoxon W & 815,500 \\
Z & $-1,531$ \\
Asymp. Sig. (2-tailed) &, 126 \\
\hline
\end{tabular}

Berdasarkan Tabel 7, terlihat bahwa rata-rata nilai wise reasoning pada selfdistance (33.82) lebih besar dibandingkan rata-rata wise reasoning pada self-immersed (27.18). Nilai ini meunjukkan terdapat perbedaan mean wise reasoning pada selfimmersed dan self-distance. Hanya saja, perbedaan mean tersebut tidak signifikan karena $p=0.126$ ( $p>0.05)$. Dengan demikian, hipotesis $\mathrm{H}_{0}$ diterima dan $\mathrm{H}_{1}$ ditolak. Hal ini berarti bahwa tidak ada perbedaan wise reasoning antara self-immersed dan selfdistance.

\section{Hipotesis Kedua}

Tabel 9

Deskripsi Pengalaman

\begin{tabular}{lccccc}
\hline & $N$ & Mean & Std. Deviation & Minimum & Maximum \\
\hline Wise & 60 & 9,12 & 1,316 & 7 & 13 \\
Pengalaman & 60 & 1,70 &, 462 & 1 & 2 \\
\hline
\end{tabular}

Tabel 10

Mean Rank Pengalaman

\begin{tabular}{lllcc}
\hline & Pengalaman & $N$ & Mean Rank & Sum of Ranks \\
\hline \multirow{2}{*}{ Wise } & Pernah & 18 & 32,97 & 593,50 \\
& Belum & 42 & 29,44 & 1236,50 \\
\cline { 2 - 5 } & Total & 60 & & \\
\hline
\end{tabular}

Tabel 11

Uji U-Mann Whitney Pengalaman

\begin{tabular}{lr}
\hline & \multicolumn{1}{c}{ Wise } \\
\hline Mann-Whitney U & 333,500 \\
Wilcoxon W & 1236,500 \\
$Z$ &,- 747 \\
Asymp. Sig. (2-tailed) &, 455 \\
\hline
\end{tabular}


Berdasarkan Tabel 10, terlihat bahwa mean rank wise reasoning untuk kelompok yang pernah mengalami sebesar 32.97, sedangkan untuk yang belum pernah mengalami sebesar 29.44. Perbedaan nilai rank tersebut menunjukkan bahwa terdapat perbedaan mean wise reasoning antara kelompok yang pernah dan belum pernah mengalami.

Namun perbedaan tersebut tidak signifikan pada taraf kepercayaan 95\%. Hal ini dilihat pada nilai signifikansi nilai $Z$ yang diperoleh, sebesar 0.455 (sig. 0.455

$>0.05)$. Oleh karena itu, hipotesis kedua ditolak. Dengan demikian, hipotesis $\mathrm{H}_{0}$ diterima dan $\mathrm{H}_{1}$ ditolak. Hal ini berarti bahwa tidak ada perbedaan antara kelompok yang pernah mengalami dan kelompok yang belum pernah mengalami.

\section{Hipotesis Ketiga}

Tabel 12

Deskripsi antara immersed pernah, immersed belum, distance pernah, dan distance belum.

\begin{tabular}{lccccc}
\hline & $N$ & Mean & $\begin{array}{c}\text { Std. } \\
\text { Deviation }\end{array}$ & Min. & Max. \\
\cline { 2 - 6 } Wise & 60 & 9,12 & 1,316 & 7 & 13 \\
imm_dis & 60 & 2,70 & 1,280 & 1 & 4 \\
\hline
\end{tabular}

Tabel 13

Mean Rank antara immersed pernah, immersed belum, distance pernah, dan distance belum.

\begin{tabular}{llcc}
\hline & \multicolumn{1}{c}{ imm_dis } & $N$ & Mean Rank \\
\hline Wise & imm_pernah & 15 & 32,87 \\
& imm_belum & 15 & 21,50 \\
& dis_pernah & 3 & 33,50 \\
& dis_belum & 27 & 33,85 \\
\cline { 2 - 4 } & Total & 60 & \\
\hline
\end{tabular}

Tabel 14

Uji Kruskal Wallis Test

\begin{tabular}{ll}
\hline & Wise \\
\hline Chi-Square & 5,789 \\
Df & 3 \\
Asymp. Sig. &, 122 \\
\hline
\end{tabular}

Terdapat perbedaan rata-rata nilai wise reasoning pada kelompok immersed maupun distance. Di mana rata-rata wise reasoning pada kelompok immersed pernah sebesar 32.87, pada kelompok immersed belum sebesar 21.50. Sedangkan rata-rata pada wise reasoning kelompok distance pernah sebesar 33.50, dan yang distance belum sebesar 33.85. Terdapat perbedaan nilai rata wise reasoning pada keempat hal tersebut. Kendati terdapat perbedaan, namun perbedaan tersebut tidak signifikan. Hal ini dilihat dari nilai chi square yang dinilainya 5,789 dimana nilai ini tidak signifikan pada taraf signifikansi 95\% (sig. $0.122>0.05$ ). Dengan demikian, hipotesis $\mathrm{H}_{0}$ diterima dan $\mathrm{H}_{1}$ ditolak. Hal ini berarti bahwa tidak ada perbedaan antara kelompok immersed pernah, immersed belum, distance pernah, dan distance belum.

\section{Diskusi}

Hasil analisis data menunjukkan bahwa terdapat perbedaan nilai rata-rata wise reasoning pada keempat hal tersebut, yakni immersed pernah, immersed belum, distance pernah, dan distance belum. Kendati terdapat perbedaan, namun perbedaan tersebut tidak signifikan. Hal ini dilihat dari nilai chi square yang dinilainya 5,789 dimana nilai ini tidak signifikan pada taraf signifikansi 95\% (sig. $0.122>0.05$ ). Hasil tersebut diperoleh melalui uji nonparametric. 
Hal tersebut dalam pengamatan peneliti dapat diakibatkan beberapa hal. Pertama, tidak adanya manipulation check. Untuk melihat apakah pada kelompok distance terjadi hal yang semestinya. Kondisi tersebut disebabkan karena pada penelitian sebelumnya, tidak dilakukan hal yang dapat memberikan informasi tambahan tentang menguji kondisi distance. Kedua, pada lembar jawaban para pesertadisediakan pertanyaan yang menguji pengalaman peserta. Sebagian besar (27 subjek dari dalam kelompok distance) pernah mengalami kasus yang diberikan. Sehingga subjek yang harusnya berada pada kondisi distance dapat menjadi immersed. Berdasarkan penelitian yang dilakukan oleh Bluck, Gluck dan McAdams (2005) bahwa pengalaman yang terjadi dapat membantu individu dalam meningkatkan kemampuannya dalam menghubung informasi. Sehingga individu yang pernah mengalami, cenderung bijaksana dibandingkan yang belum.

Penelitian Kross dan Grossman (2011) yang menjelaskan bahwa individu dapat gagal menjadi bijaksana bila berada pada kondisi immersed dan akan lebih bijaksana dengan kondisi distance mendapatkan hasil yang berbeda dengan adanya pengalaman atau proses mengingat yang dilakukan oleh subjek penelitian. Proses mengingat pengalaman kebijaksanaan yang penting bagi kisah hidup karena dua alasan. Pertama, kebijaksanaan dapat digunakan dalam menangani pengalaman signifikan yang berperan sebagai titik balik dalam kehidupan. Kedua, pengalaman ini adalah yang dapat bermanfaat (Bandura, 1977) dalam menghadapi perubahan atau ketidakpastian, sehingga dalam mengingat pengalaman tersebut dan mengintegrasikannya dalam kisah hidup mungkin dapat meningkatan kualitas diri (Wilson \& Ross, 2000).
Hal tersebut mendukung penelitian yang membuktikan bahwa Setiap individu dapat menjadi bijaksana jika memiliki kemampuan mengingat dan mengaitkan pengalaman yang pernah dimiliki, terlebih dalam pengalaman yang menuntut kebijaksanaan. Gagasan bahwa setiap individu dapat menjadi bijaksana (Randall \& Kenyon, 2000), muncul dari proses mengingat pengetahuan yang benar, atau menggunakan pengetahuan dengan cara yang benar (McKee \& Barber,1999), atau dipengaruhi dari individu serta lingkungan yang tepat (Sternberg, 2005), menunjukkan bahwa individu harus (seperti yang kita minta untuk pendekatan ini) dapat mengingat dan menceritakan situasi setidaknya satu kehidupan di mana mereka merasa bahwa mereka bertindak bijaksana.

Maka dari itu, setiap individu yang pernah maupun belum mengalami kondisi dalam penelitian ini tergantung dari kemampuan dalam mengingat pengalaman yang pernah dialami. Akhirnya, individu harus mengingat jenis situasi (misalnya, membuat keputusan hidup) yang konsisten dengan model lain kebijaksanaan. Yang lebih dikenal dengan istilah wisdom experience (Bluck \& Gluck, 2004).

\section{Kesimpulan}

Setiap individu yang pernah maupun yang belum memiliki kekuatan pengalaman seperti dalam penelitian ini, tergantung dari kemampuannya dalam mengingat pengalaman yang pernah dialami. Pada akhirnya, individu harus mengingat jenis situasi (misalnya, membuat keputusan hidup) yang konsisten dengan model lain kebijaksanaan. Yang lebih dikenal dengan istilah wisdom experience (Bluck \& Gluck, 2004). Pengaruh psychological 
distance bila dirumuskan bersama dengan pengalaman dapat memberikan pemahaman baru untuk dapat kita kaji lebih dalam. Tentu saja, individu dapat menjadi bijaksana jika mampu belajar dari pengalaman dan berdiri dengan posisi distance demi mendapatkan objektivitas dalam memandang suatu masalah yang ada.

\section{Kepustakaan}

Ayduk, Ö., \& Kross, E. (2010). From a distance: Implications of spontaneous self-distancing for adaptive selfreflection. Journal of Personality and Social Psychology, 98, 809-829.

Ayduk, O., Mischel, W., \& Downey, G. (2002). Attentional mechanismslinking rejection to hostile reactivity: The role of "hot" versus "cool" focus. Psychological Science, 13, 443-448. http://dx.doi.org/10.1111/1467-9280.00478.

Baltes, P. B., \& Smith, J. (1990). Toward a psychology of wisdom and its ontogenesis. In R. J. Sternberg (Ed.), Wisdom: Its nature, origins, and development. Cambridge: Cambridge University Press.

Baltes, P. B., Smith, J., \& Staudinger, U. M. (1992). Wisdom as successful aging. In T. B. Sonderegger (Ed.), Nebraska Symposium on Motivation (Vol. 39, pp. 123-167). Lincoln: University of Nebraska Press.

Baltes, P. B., \& Staudinger, U. M. (2000). Wisdom: A metaheuristic (pragmatic) to orchestrate mind and virtue toward excellence. American Psychologist, 55, 122-136.

Bandura, A. (1977). Social learning theory (2nd ed.). Englewood Cliffs, NJ: Prentice-Hall.
Basseches, M. (1980). Dialectical schemata: A framework for the empirical study of the development of dialectical thinking. Human Development, 23, 404 421. http://dx.doi.org/10.1111/10.1159/ 000272600.

Glück, J., Bluck, S., Baron, J., \& McAdams, D. P. (2005).The wisdom of experience: Autobiographical narrativesacross adulthood. International Journal of Behavioral Development, 29(3), 197-208. http://dx.doi.org/10.1177/016502504440 00504

Bluck, S., \& Glück, J. (2004) Making Things Better and Learning a Lesson: Experiencing Wisdom Across the Lifespan. Journal of Personality 72(3).

Grossmann, I. (January 13, 2015). Personal communication by email.

Grossmann, I., Na, J., Varnum, M. E. W., Park, D. C., Kitayama, S., \& Nisbett, R. E. (2010). Reasoning about social conflicts improves into old age. Proceedingsof the National Academy of Sciences, USA, 107, 7246-7250. http://dx.doi.org/10.1073/pnas.1001715 107.

Grossmann, I., Na, J., Varnum, M. E. W., Kitayama, S., \& Nisbett, R. E. (2013). A route to well-being: Intelligence versus wise reasoning. Journal of Experimental Psychology: General, 142, 944-953. http://dx.doi.org/10.1037/a0029560

Kramer, D., \& Woodruff, D. S. (1986). Relativistic and dialectical thoughtin three adult age-groups. Human Development, 29, 280-290. http://dx.doi.org/10.1111/10.1159/00027 3064

Kross, E., Ayduk, O., \& Mischel, W. (2005). When asking "why" does not hurt: Distinguishing rumination from reflective processing of negative 
emotions. Psychological Science, 16, 709-715.

Kross, E., \& Grossmann, I. (2011). Boosting wisdom: Distance from the self enhances wise reasoning, attitudes, and behavior. Journal of Experimental Psychology: General, 141, 43-48. http://dx.doi.org/10.1111/10.1037/a0024 158.

Lerner, R. M., Easterbrooks, M. A., \& Mistry, J. (2003). Handbook of psychology. Vol. 6 Developmental Psychology. USA: John Wiley \& Sons, Inc.

McKee, P., \& Barber, C. (1999). On defining wisdom. International Journal of Human Development, 49, 149-164.

Randall, W. L., \& Kenyon, G. M. (2000). Ordinary wisdom: Biographical aging and the journey of life. Westport, CT: Praeger.

Seniati, L., Yulianto, A., \& Setiadi, B. N. (2005). Psikologi eksperimen. Jakarta: PT Indeks.

Snyder, C., \& Lopez, S. (2002). Handbook of positive psychology. NewYork: Oxford University Press.

Staudinger, U. M., \& Glück, J. (2011). Psychological wisdom research. Annual Review of Psychology, 62, 215241.

Staudinger, U. M., Smith, J., \& Baltes, P. B. (1994). Manual for the assessment of wisdom-related knowledge (Materialien aus der Bildungsforschung No. 46). Berlin: Max Planck Institute for Human Development and Education.

Staudinger, U. M., Lopez, D., \& Baltes, P. B. (1997). The psyhometric location of wisdom-related performance: Intelligence, personality, and more? Personality and Social Psychology Bulletin, 23, 1200-1214.

Sternberg, R., \& Jordan, J. (2005). A Handbook of wisdom: Psychological perspectives. New York: Cambridge University Press.

Trope, Y., \& Liberman, N. (2010). Construal-level theory of psychological distance. Psychological Review, 117, 440-463. http://dx.doi.org/10.1111/10. 1037/a0018963

Verduyn, P., Van Mechelen, I., Kross, E., Chezzi, C., \& Van Bever, F. (2012, May 28). The Relationship Between SelfDistancing and the Duration of Negative and Positive Emotional Experiences in Daily Life. Emotion Advance online publication. http://dx.doi.org/10.1037/ a0028289.

Wilson, A. E., \& Ross, M. (2000). The frequency of temporal-self and social comparisons in people's personal appraisals. Journal of Personality and Social Psychology, 78, 928-942. 